The Canadian Mineralogist

Vol. 42, pp. 835-840 (2004)

\title{
THE CRYSTAL STRUCTURE OF SKIPPENITE, $\mathrm{Bi}_{2} \mathrm{Se}_{2} \mathrm{Te}$, FROM THE KOCHKAR DEPOSIT, SOUTHERN URALS, RUSSIAN FEDERATION
}

\author{
LUCA BINDI ${ }^{\S}$ AND CURZIO CIPRIANI \\ Museo di Storia Naturale - sez. di Mineralogia e Litologia, Università degli Studi di Firenze, \\ via La Pira 4, I-50121 Firenze, Italy
}

\begin{abstract}
Skippenite, $\mathrm{Bi}_{2} \mathrm{Se}_{2} \mathrm{Te}$, was found in a sample from the Kochkar deposit, southern Urals, Russian Federation. The sample forms part of the mineralogical collection of the Natural History Museum of the University of Florence. Electron-microprobe analyses gave the chemical formula $\left(\mathrm{Bi}_{2.06} \mathrm{Cu}_{0.05} \mathrm{Sb}_{0.03}\right)_{\Sigma 2.14} \mathrm{Se}_{2.00}\left(\mathrm{Te}_{0.89} \mathrm{~S}_{0.11}\right)$. The mineral occurs as anhedral grains up to 0.3 $\mathrm{mm}$ across. Skippenite is steel-grey in color, shows a black streak, and has a perfect basal cleavage. In reflected light, the mineral is greyish white, weakly bireflectant, nonpleochroic, moderately anisotropic in yellowish tints. Reflectivity values $\left(R_{\min }\right.$ and $R_{\max }$, in \%) are 47.8, $48.1(471.1 \mathrm{~nm}), 49.0,50.2(548.3 \mathrm{~nm}), 49.1,50.3(586.6 \mathrm{~nm})$, and 49.3, $50.7(652.3 \mathrm{~nm})$, respectively. Skippenite is trigonal, space group $R \overline{3} \mathrm{~m}$, with the following unit-cell parameters: $a 4.183(1), c 29.137(3) \AA, V 441.5(2) \AA^{3}$ and $Z=3$. The crystal structure has been refined to $R=2.93 \%$. It consists of hexagonal close-packed sheets of $\mathrm{Bi}, \mathrm{Se}$ and $\mathrm{Te}$, respectively. The unit-cell of skippenite contains 15 layers, and the stacking sequence is: A'cBAc-B' ${ }^{a C B a}-C^{\prime} b A C b$, where A', B', C' $=$ Te and $\mathrm{S}, \mathrm{A}, \mathrm{B}, \mathrm{C}=\mathrm{Se}$, and a, b, c, = Bi.
\end{abstract}

Keywords: skippenite, Bi-Se telluride, chemical composition, physical properties, crystal-structure refinement, Kochkar, Russia.

\section{SOMMAIRE}

Nous avons trouvé la skippenite, $\mathrm{Bi}_{2} \mathrm{Se}_{2} \mathrm{Te}$, dans un échantillon provenant du gisement de Kochkar, dans le secteur sud des Ourales, Fédération Russe. Cet échantillon fait partie de la collection minéralogique du Musée d'Histoire Naturelle de l'Université de Florence. Les analyses effectuées avec une microsonde électronique ont mené à la formule chimique $\left(\mathrm{Bi}_{2.06} \mathrm{Cu}_{0.05} \mathrm{Sb}_{0.03}\right)_{\Sigma 2.14}$ $\mathrm{Se}_{2.00}\left(\mathrm{Te}_{0.89} \mathrm{~S}_{0.11}\right)$. Le minéral se présente en grains xénomorphes atteignant $0.3 \mathrm{~mm}$. La skippenite, de couleur gris acier, possède une rayure noire et un clivage parfait le long des feuillets. En lumière réfléchie, elle est blanc grisâtre, faiblement biréflectante, non pléochrö̈que, et modérément anisotrope en teintes jaunâtres. Les valeurs de réflectivité $\left(R_{\min }\right.$ et $R_{\max }$, en \%) sont $47.8,48.1$ $(471.1 \mathrm{~nm}), 49.0,50.2(548.3 \mathrm{~nm}), 49.1,50.3(586.6 \mathrm{~nm})$, et 49.3, $50.7(652.3 \mathrm{~nm})$, respectivement. La skippenite est trigonale, groupe spatial $R 3 \mathrm{~m}$, avec les paramètres réticulaires $a 4.183(1), c 29.137(3) \AA ⿻$, $V 441.5(2) \AA^{3}$ et $Z=3$. Nous avons affiné la structure cristalline jusqu'à un résidu $R$ de $2.93 \%$. Elle est faite de feuillets à empilement hexagonal compact d'atomes $\mathrm{Bi}$, Se et Te. La maille élémentaire contient quinze couches, et la séquence d'empilement serait A'cBAc-B' $\mathrm{aCBa}-\mathrm{C}$ 'bACb, avec A', B', $\mathrm{C}^{\prime}=\mathrm{Te}$ et $\mathrm{S}, \mathrm{A}, \mathrm{B}, \mathrm{C}=\mathrm{Se}$, et a, b, c, = Bi.

(Traduit par la Rédaction)

Mots-clés: skippenite, tellurure de Bi et Se, composition chimique, propriétés physiques, affinement de la structure cristalline, Kochkar, Russie.

\section{INTRODUCTION}

In order to evaluate the extent of solid solution between the synthetic end-members $\mathrm{Bi}_{2} \mathrm{Te}_{3}$ and $\mathrm{Bi}_{2} \mathrm{Se}_{3}$, Nakajima (1963) synthesized compounds having the chemical composition $\mathrm{Bi}_{2} \mathrm{Te}_{3-x} \mathrm{Se}_{x}$, with $x=0,1,2$ and 3 . This author established the crystal structure of these synthetic compounds (i.e., $\mathrm{Bi}_{2} \mathrm{Te}_{3}, \mathrm{Bi}_{2} \mathrm{SeTe}_{2}, \mathrm{Bi}_{2} \mathrm{Se}_{2} \mathrm{Te}$ and $\mathrm{Bi}_{2} \mathrm{Se}_{3}$ ) in the space group $R \overline{3} m$ and reported a detailed study of the relations between the crystallographic data and physical properties. More recently, Dumas et al. (1987) showed that the phase relations along the join $\mathrm{Bi}_{2} \mathrm{Te}_{3}-\mathrm{Bi}_{2} \mathrm{Se}_{3}$ have a more complex subsolidus pattern than previously recognized, and that the range of solid solution for end-member $\mathrm{Bi}_{2} \mathrm{Te}_{3}$ only partially extended toward $\mathrm{Bi}_{2} \mathrm{Te}_{2} \mathrm{Se}$. Moreover, Sokolov et al. (2004) have presented data for the $\mathrm{Bi}_{2} \mathrm{Te}_{3}-\mathrm{Bi}_{2} \mathrm{Te}_{2} \mathrm{Se}$ segment of the phase system showing that solid solution in tellurobismuthite, ideally $\mathrm{Bi}_{2} \mathrm{Te}_{3}$, extends only to 14 mol. $\%$ of $\mathrm{Bi}_{2} \mathrm{Se}_{3}$.

$\S \quad$ E-mail address: 1bindi@steno.geo.unifi.it 
The natural analogue of the synthetic $\mathrm{Bi}_{2} \mathrm{Se}_{2} \mathrm{Te}$, was found by Johan et al. (1987) during a study of selenide and telluride minerals at the Otish Mountains basin, Quebec, Canada. The mineral, named skippenite, occurs as massive aggregates of lamellar crystals intimately associated with watkinsonite, $\mathrm{Cu}_{2} \mathrm{PbBi}_{4}(\mathrm{Se}, \mathrm{S})_{8}$, and with unnamed bismuth selenides whose composition is close to $\mathrm{Bi}_{2}(\mathrm{Se}, \mathrm{Te}, \mathrm{S})_{2}$ and $(\mathrm{Bi}, \mathrm{Pb})_{2}(\mathrm{Se}, \mathrm{Te}, \mathrm{S})_{3}$. By means of an X-ray single-crystal study (Weissenberg photographs), Johan et al. (1987) pointed out that skippenite is rhombohedral with $a$ 4.183(4), $c$ 29.12(8) $\AA, V 441.3$ $\AA^{3}, Z=3$. In addition, by analogy with the compounds having a tetradymite-like structure (Harker 1934), these authors attributed the space group $R \overline{3} m$ to skippenite. However, taking into account the fact that the skippenite crystals were strongly deformed and of a soft platy nature, Johan et al. (1987) did not carry out a crystal-structure refinement.

More recently, in a review of the minerals occurring at the Bambolla, Bambollita and San Miguel mines, Braith et al. (2001) reported a further occurrence of skippenite from Sonora, Moctezuma, Mexico. However, their study was limited to a description of the occurrence; they did not report new information on skippenite. In addition, skippenite was found from the Kurile-Kamchatka belt by Kovalenker et al. (1989), and from the Kochkar deposit (Spiridonov 1995).

In the course of a research project dealing with the characterization of tellurium-bearing minerals of the mineralogical collection of the Natural History Museum of Florence (Bindi \& Cipriani 2003a, b, 2004a, b, Cipriani \& Bindi 2004), we discovered a further occurrence of skippenite from the Kochkar deposit, southern Urals, Russian Federation (catalogue number 48034/G, labeled saddlebackite). Associated minerals are aleksite, $\mathrm{PbBi}_{2} \mathrm{Te}_{2} \mathrm{~S}_{2}$, and galena. The mineral occurs as anhedral grains up to $0.3 \mathrm{~mm}$.

In this paper, we provide a physical and chemical characterization of skippenite from the Kochkar deposit, together with a refinement of the crystal structure.

\section{OCCURRENCE}

The Kochkar gold district in the East Uralian Zone of the southern Urals is located in late Paleozoic granitic gneisses of the Plast massif. Gold mineralization is associated with tabular quartz lodes that are preferentially developed along the margins of easterly trending mafic dykes (Kisters et al. 2000). Deformation and formation of associated gold-quartz lodes occurred close to the peak of metamorphism at conditions of the upper-greenschist to lower-amphibolite facies. Fracturing in the gneissic rocks promoted the access of mineralizing fluids (Kisters et al. 2000). Both ore-controlling dykes and gold-quartz lodes were subsequently overprinted by lower greenschist-facies assemblages, and an associated hydrothermal alteration postdated the gold mineralization. In the Kochkar gold deposit, mineral- ization is linked to mylonitized dykes, intrafolial folds and shear bands, which confirms the late nature of mineralization. All the quartz veins show evidence of recrystallization; this is evidence of a dynamic regime of formation on a regional scale.

\section{Physical and Optical Properties}

Skippenite is steel grey and shows a black streak. The mineral is opaque with a high metallic luster. Crystals are flattened along [0001], with a perfect $\{0001\}$ cleavage. The dominant form is $\{0001\}$, and twinning is not observed. The micro-indentation measurements carried out with a VHN load of $25 \mathrm{~g}$ gave a mean value of $66 \mathrm{~kg} / \mathrm{mm}^{2}$ (range: $60-71$ ), corresponding to a Mohs hardness of about $2 \frac{1}{2}-3$. This value is in good agreement with that found by Johan et al. (1987) for skippenite from the type locality $\left(63 \mathrm{~kg} / \mathrm{mm}^{2}\right)$.

In reflected light, skippenite is greyish white, weakly bireflectant, nonpleochroic, moderately anisotropic in yellowish tints. Internal reflections are absent.

Reflectance measurements were performed in air by means of a MPM-200 Zeiss microphotometer equipped with a MSP-20 system processor on a Zeiss Axioplan ore microscope. The temperature of the filament was approximately $3350 \mathrm{~K}$. An interference filter was adjusted, in turn, to select four wavelengths for measurement $(471.1,548.3,586.6$, and $652.3 \mathrm{~nm})$. Readings were taken for specimen and standard $(\mathrm{SiC})$ maintained under the same focus conditions. The diameter of the circular area for measurement was $0.1 \mathrm{~mm}$. Measurements of reflectivity (in \%) for $R_{\min }$ and $R_{\max }$ are 47.8 , $48.1(471.1 \mathrm{~nm}), 49.0,50.2(548.3 \mathrm{~nm}), 49.1,50.3$ $(586.6 \mathrm{~nm})$, and $49.3,50.7(652.3 \mathrm{~nm})$, respectively. Figure 1 illustrates the excellent agreement between the reflectance percentages obtained for the skippenite studied here with those measured by Johan et al. (1987) for type-locality skippenite.

\section{Chemical Composition}

A preliminary chemical analysis using EDS, performed on the same crystal fragment used for the structural study, did not indicate elements $(Z>9)$ other than $\mathrm{Bi}, \mathrm{Te}, \mathrm{Se}$ and very minor $\mathrm{Cu}, \mathrm{Pb}, \mathrm{Sb}$ and $\mathrm{S}$. The chemical composition was then determined with a JEOL JXA8600 electron microprobe. Concentrations of the major and minor elements were determined at an accelerating voltage of $20 \mathrm{kV}$ and a beam current of $40 \mathrm{nA}$, with variable counting times: $30 \mathrm{~s}$ was used for $\mathrm{Bi}$, Te and $\mathrm{Se}$, and $60 \mathrm{~s}$ for the minor elements $\mathrm{Cu}, \mathrm{Pb}, \mathrm{Sb}$ and $\mathrm{S}$. For the wavelength-dispersion analyses, the following lines were used: $\mathrm{Bi} M \alpha, \operatorname{Te} L \alpha, \operatorname{Se} K \alpha, \mathrm{Cu} K \alpha, \mathrm{Pb} M \alpha$, $\mathrm{Sb} L \beta, \mathrm{S} K \alpha$. We employed the following standards: pure bismuth (Bi), synthetic $\mathrm{Sb}_{2} \mathrm{Te}_{3}(\mathrm{Sb}, \mathrm{Te})$, clausthalite $(\mathrm{Se})$, pure copper $(\mathrm{Cu})$, galena $(\mathrm{Pb}, \mathrm{S})$. The crystal fragment was found to be homogeneous within analytical uncertainty. The average chemical composition (15 


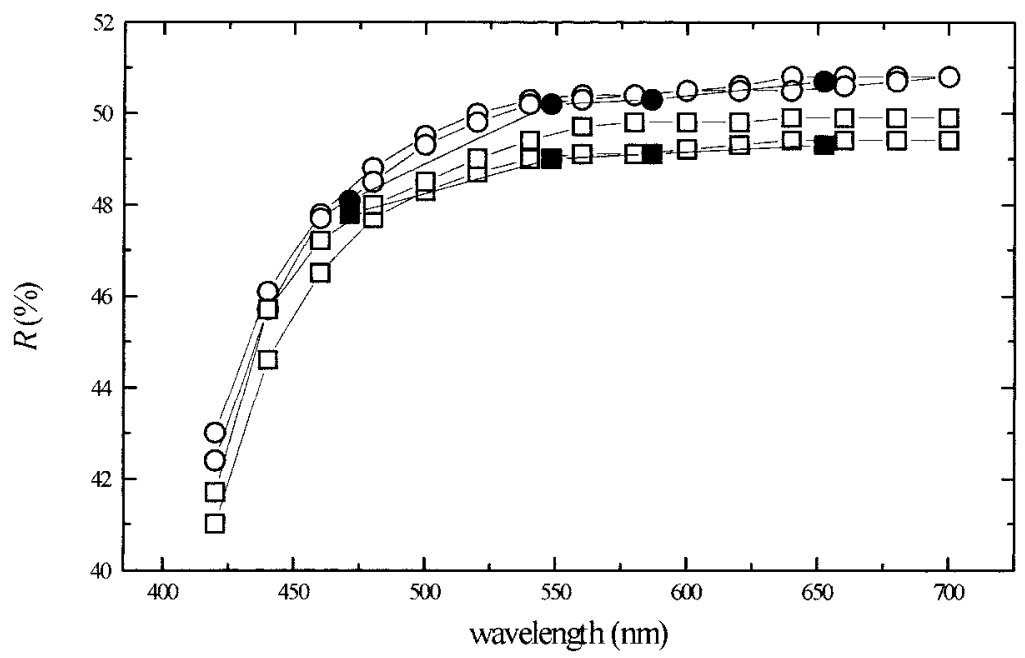

FIG. 1. Reflectivity curves for skippenite samples in air. Open symbols refer to holotype skippenite (two grains; Johan et al. 1987), filled symbols refer to skippenite from Kochkar deposit (this study). Circles and squares refer to $R_{\max }$ and $R_{\min }$ values, respectively.

\begin{tabular}{lccc}
\multicolumn{4}{c}{$\begin{array}{c}\text { TABLE 1. COMPOSITION OF SKIPPENITE FROM THE KOCHKAR DEPOSIT, } \\
\text { SOUTHERN URALS, RUSSIA }\end{array}$} \\
\hline element & & range & $\sigma(\%)$ \\
\hline & wt. $\%$ & & \\
$\mathrm{Cu}$ & & $0.22-0.55$ & 0.02 \\
$\mathrm{~Pb}$ & 0.42 & $0.06-0.18$ & 0.01 \\
$\mathrm{Bi}$ & 0.11 & $59.65-61.08$ & 0.30 \\
$\mathrm{Sb}$ & 60.18 & $0.22-0.54$ & 0.02 \\
$\mathrm{Se}$ & 0.44 & $21.88-22.43$ & 0.30 \\
$\mathrm{~S}$ & 22.10 & $0.24-0.71$ & 0.01 \\
$\mathrm{Te}$ & 0.50 & $15.66-15.99$ & \\
& 15.82 & & \\
total & 99.57 & & \\
& & &
\end{tabular}

analyses on different spots), together with ranges of element concentrations, are reported in Table 1 . On the basis of 3( $\mathrm{Se}+\mathrm{Te}+\mathrm{S})$, the formula of skippenite studied here is $\left(\mathrm{Bi}_{2.06} \mathrm{Cu}_{0.05} \mathrm{Sb}_{0.03}\right)_{\Sigma 2.14} \mathrm{Se}_{2.00}\left(\mathrm{Te}_{0.89} \mathrm{~S}_{0.11}\right)$, which compares favorably with that reported by Johan et al. (1987): $\left(\mathrm{Bi}_{2.05} \mathrm{Cu}_{0.04} \mathrm{~Pb}_{0.01}\right)_{\Sigma 2.10} \mathrm{Se}_{2.00}\left(\mathrm{Te}_{0.87} \mathrm{~S}_{0.13}\right)$.

\section{Crystal-Structure Refinement}

A small tabular fragment $(10 \times 25 \times 25 \mu \mathrm{m})$ was selected for the X-ray single-crystal diffraction study. Unit-cell parameters, determined by centering 25 high$\theta\left(22-25^{\circ}\right)$ reflections on a Nonius Mach-3 automated diffractometer, are shown in Table 2. Intensity data were collected using MoK$\alpha$ radiation monochromatized by a flat graphite crystal in $\omega$ scan mode. Intensities were corrected for Lorentz and polarization effects, and subsequently for absorption following the semi-empirical method of North et al. (1968); the values of the trigonal

\begin{tabular}{|c|c|}
\hline Space group & $R \overline{3} m$ \\
\hline Unit-cell parameters & \\
\hline $\begin{array}{l}a(\AA) \\
c(\AA)\end{array}$ & $\begin{array}{l}4.183(1) \\
29.137(3)\end{array}$ \\
\hline $\begin{array}{l}c(\AA) \\
V\left(\AA^{3}\right)\end{array}$ & $\begin{array}{l}29.137(3) \\
441.5(2)\end{array}$ \\
\hline Crystal size $(\mu \mathrm{m})$ & $10 \times 25 \times 25$ \\
\hline Wavelength & $\operatorname{Mo} K \alpha(50 \mathrm{kV}, 30 \mathrm{Ma}$ \\
\hline Theta range $\left({ }^{\circ}\right)$ & $1-25$ \\
\hline Scan mode & $\omega$ \\
\hline Scan width $\left(^{\circ}\right)$ & 2.75 \\
\hline Scan speed ( $/ / \mathrm{min})$ & 2.06 \\
\hline Independent reflections & 131 \\
\hline Reflections with $F_{o}>4 \sigma\left(F_{o}\right)$ & 125 \\
\hline$R_{\mathrm{obs}}(\%)$ & 2.93 \\
\hline$R_{\text {all }}(\%)$ & 3.00 \\
\hline
\end{tabular}

equivalent pairs were averaged. The merging $R$ for the $\Psi$-scan data set decreased from $18.29 \%$ before the absorption correction to $3.81 \%$ after this correction. The structure refinement was performed in the space group $R \overline{3} m$, starting from the atom coordinates of the synthetic $\mathrm{Bi}_{2} \mathrm{Se}_{2} \mathrm{Te}$ (Nakajima 1963), using the program SHELXL-97 (Sheldrick 1997). The introduction of anisotropic temperature-factors for all the atoms led to $R=2.93 \%$ for 125 observed reflections $\left[\mathrm{F}_{\mathrm{o}}>4 \sigma\left(\mathrm{F}_{\mathrm{o}}\right)\right]$ and $R=3.00 \%$ for all 131 independent reflections. Neutral scattering curves for $\mathrm{Bi}, \mathrm{Te}$ and $\mathrm{Se}$ were taken from The International Tables of X-ray Crystallography, volume IV (Ibers \& Hamilton 1974). Inspection of the difference-Fourier map revealed that maximum positive and negative peaks were 2.00 and $1.77 e^{-} / \AA^{3}$, respectively. Experimental details and $R$ indices are given in Table 2. Fractional coordinates of the atoms and anisotropic-displacement parameters are shown in Table 3. 
A list of the observed and calculated structure-factors is available from the Depository of Unpublished Data, CISTI, National Research Council, Ottawa, Ontario K1A 0S2, Canada.

\section{RESULTS}

Skippenite is a member of the tetradymite group, as defined by Bayliss (1991). This group of minerals consists of hexagonal close-packed sheets linked by van der Waals bonding, with variable stacking sequences that give the $\mathbf{c}$ axis from $3 \times 6 \AA$ to $12 \times 6 \AA$ (Strunz \& Nickel 2001). In the subgroup with the c axis $\sim 5 \times 6 \AA$, there are seven members: tellurantimony, $\mathrm{Sb}_{2} \mathrm{Te}_{3}$ (Thorpe \& Harris 1973, Effenberger \& Pertlik 1987), paraguanajuatite, $\mathrm{Bi}_{2}(\mathrm{Se}, \mathrm{S})_{3}$ (Shimizu et al. 1988), tetradymite, $\mathrm{Bi}_{2} \mathrm{Te}_{2} \mathrm{~S}$ (Harker 1934, Pauling 1975), tellurobismuthite, $\mathrm{Bi}_{2} \mathrm{Te}_{3}$ (Thompson 1949, Effenberger \& Pertlik 1987), kawazulite, $\mathrm{Bi}_{2} \mathrm{Te}_{2} \mathrm{Se}$ (Kato 1970), skippenite, $\mathrm{Bi}_{2} \mathrm{Se}_{2} \mathrm{Te}$ (Johan et al. 1987), and saddlebackite, $\mathrm{Pb}_{2} \mathrm{Bi}_{2} \mathrm{Te}_{2} \mathrm{~S}_{3}$ (Clarke 1997). If we leave out saddlebackite, which has a different structure (N.J. Cook, pers. commun.), all the others are characterized by space group $R \overline{3} \mathrm{~m}$, unit-cell dimensions $a$ in the range 4.13-4.38 $\AA, 28.58<c<33.43 \AA$ and $Z=3$. The size of the unit-cell parameters for Bi-dominant members of the

\begin{tabular}{|c|c|c|c|c|c|c|c|}
\hline$x / a y / b$ & $z / c$ & $U_{n}$ & $U_{22}$ & $U_{33}$ & $U_{12}$ & $U_{H 3} U_{23}$ & $U_{e q}$ \\
\hline $\begin{array}{ll}0 & 0\end{array}$ & $0.39806(3)$ & $0.0407(6)$ & $U_{n}$ & $0.0356(9)$ & $0.0203(3)$ & $\begin{array}{ll}0 & 0\end{array}$ & $0.0390(6)$ \\
\hline $\begin{array}{ll}0 & 0 \\
0\end{array}$ & $0.2116(1)$ & $0.0274(8)$ & $U_{n}$ & $0.0209(9)$ & $0.0137(4)$ & $\begin{array}{ll}0 & 0\end{array}$ & $0.0252(6)$ \\
\hline $\begin{array}{ll}0 & 0\end{array}$ & 0 & $0.0372(9)$ & $U_{11}$ & $0.0252(9)$ & $0.0186(4)$ & $\begin{array}{ll}0 & 0\end{array}$ & $0.0332(7)$ \\
\hline
\end{tabular}

TABLE 4. X-RAY POWDER-DIFFRACTION PATTERNS FOR SKIPPENITE

\begin{tabular}{|c|c|c|c|c|c|c|c|c|c|}
\hline \multirow[b]{2}{*}{$h k l$} & \multicolumn{2}{|c|}{1} & \multicolumn{2}{|c|}{2} & \multirow[b]{2}{*}{$h k l$} & \multicolumn{2}{|c|}{1} & \multicolumn{2}{|c|}{2} \\
\hline & $d_{\text {caik }}$ & $I / I_{c u l c}$ & $d_{\mathrm{obs}}$ & $H / I_{a}$ & & $d_{c u l c}$ & $H / I_{\text {culc }}$ & $d_{c h k}$ & $I / I_{\theta}$ \\
\hline 003 & 9.712 & 26 & 9.71 & 5 & 02.10 & 1.5383 & 10 & 1.537 & 4 \\
\hline 006 & 4.856 & 10 & 4.85 & 6 & 20.11 & 1.4952 & 1 & & \\
\hline 101 & 3.5949 & 9 & 3.584 & 6 & 11.15 & 1.4233 & 12 & 1.422 & 5 \\
\hline 012 & 3.5155 & 3 & - & & 02.13 & 1.4088 & 2 & & \\
\hline 104 & 3.2436 & 4 & 3.237 & 2 & 01.20 & 1.3516 & 4 & 1.350 & 3 \\
\hline 015 & 3.0766 & 100 & 3.074 & 10 & 125 & 1.3329 & 12 & 1.332 & 4 \\
\hline 018 & 2.5684 & 7 & 2.562 & 1 & 128 & 1.2816 & 1 & 1.283 & 2 \\
\hline 10.10 & 2.2704 & 37 & 2.267 & 7 & 11.18 & 1.2801 & 3 & - & \\
\hline 01.11 & 2.1382 & 5 & 2.133 & 5 & 21.10 & 1.2392 & 8 & 1.239 & 4 \\
\hline 110 & 2.0915 & 33 & 2.090 & 8 & 12.11 & 1.2163 & 1 & - & - \\
\hline 113 & 2.0446 & 3 & - & & 300 & 1.2075 & 4 & - & - \\
\hline 00.15 & 1.9425 & 6 & 1.944 & 3 & 01.23 & 1.1958 & 2 & - & - \\
\hline 116 & 1.9209 & 4 & 1.916 & 3 & 21.13 & 1.1684 & 2 & - & - \\
\hline 10.13 & 1.9060 & 5 & 1.080 & & 11.21 & 1.1562 & 1 & - & - \\
\hline 021 & 1.8078 & 1 & 1.808 & 2 & 20.20 & 1.1352 & 2 & - & - \\
\hline 205 & 1.7297 & 17 & 1.730 & 4 & 10.25 & 1.1095 & 1 & - & . \\
\hline 10.16 & 1.6270 & 2 & - & & 20.23 & 1.0381 & 1 & - & - \\
\hline 208 & 1.6218 & 1 & 1.622 & 3 & 03.15 & 1.0255 & 2 & - & - \\
\hline 00.18 & 1.6187 & I & - & & 30.15 & 1.0255 & 2 & . & - \\
\hline
\end{tabular}

1: $d$ values (in $\AA$ ) calculated on the basis of $a 4.183(1), c$ 29.137(3) $\AA$ and with the 1: d values (in $A$ ) calculated on the basis of $a 4,183(1), c$ cordinates reported in Table 2 . Intensities calculated using XPOW software version 2.0 (Downs et al 1993)

2: observed powder-pattern and indexing originally reported by Johan et al. (1987). tetradymite group appears to be a function of the tellurium content. Indeed, the higher the content of tellurium, the larger the unit-cell dimensions (see Strunz \& Nickel 2001). Data for skippenite are relatively consistent with the parameters predicted for the chemical composition observed.

On the whole, the crystal structure of skippenite refined here is topologically identical to that previously determined on the synthetic compound $\mathrm{Bi}_{2} \mathrm{Se}_{2} \mathrm{Te}$ by Nakajima (1963). It simply consists of hexagonal closepacked sheets of $\mathrm{Bi}, \mathrm{Se}$ and Te, respectively (Fig. 2). The unit cell of skippenite contains 15 layers, and the stacking sequence is: $\mathrm{A}^{\prime} \mathrm{cBAc}-\mathrm{B}{ }^{\prime} \mathrm{aCBa}-\mathrm{C}^{\prime} \mathrm{bACb}$ where $\mathrm{A}^{\prime}, \mathrm{B}^{\prime}, \mathrm{C}^{\prime}=\mathrm{Te}, \mathrm{S} ; \mathrm{A}, \mathrm{B}, \mathrm{C}=\mathrm{Se}$ and a,b,c, = Bi. This stacking sequence confirms the one inferred by Johan et al. (1987) in a comparison of skippenite to other members of the tetradymite group [i.e., $\mathrm{Bi}_{2} \mathrm{Se}_{3}, \mathrm{Strunz}$ (1963); kawazulite, $\mathrm{Bi}_{2} \mathrm{Te}_{2} \mathrm{Se}$, Kato (1970)].

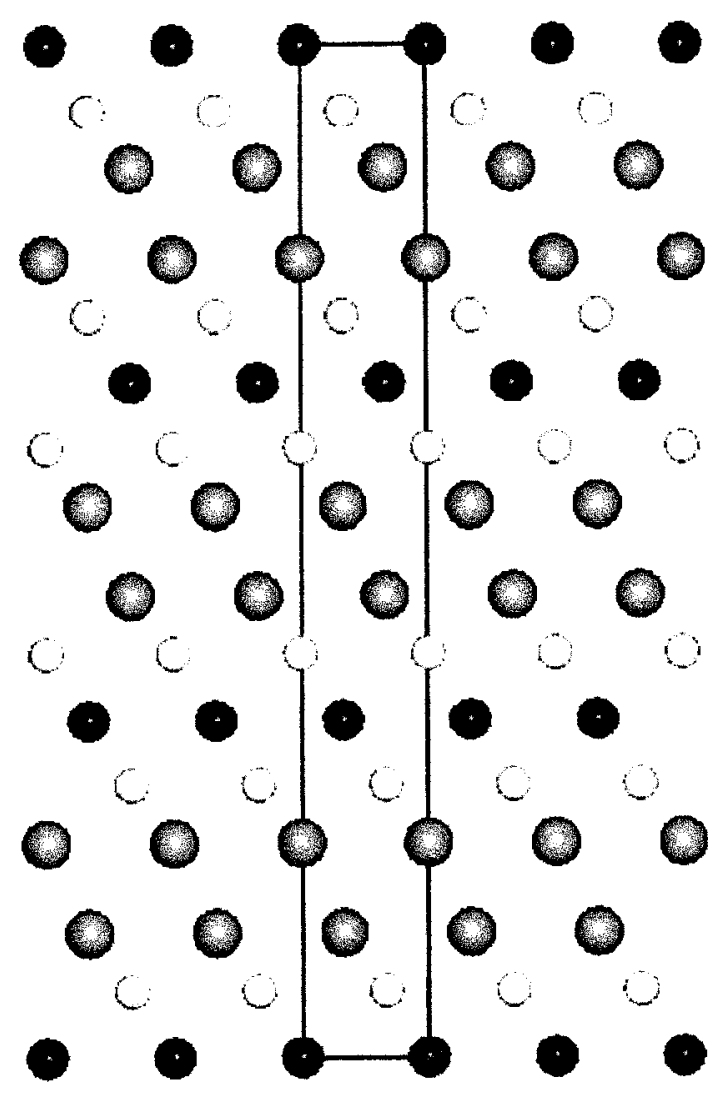

FIG. 2. The crystal structure of skippenite projected along the a axis. White, grey and black circles refer to $\mathrm{Bi}$, Se and $(\mathrm{Te}, \mathrm{S})$ atoms, respectively. The unit cell is outlined. 
The bond lengths between the sheets are: $\mathrm{Bi}-\mathrm{Se}=$ 2.931(1) $\AA, \mathrm{Bi}-\mathrm{Te}=3.064(1) \AA, \mathrm{Bi}-\mathrm{Bi}=4.183(1) \AA$, $\mathrm{Te}-\mathrm{Te}=4.184(1) \AA, \mathrm{Se}-\mathrm{Se}=3.564(3) \AA, \mathrm{Te}-\mathrm{Se}=$ 4.290 (2) $\AA$, respectively. These values match closely those observed for the structure of telluronevskite, $\mathrm{Bi}_{3} \mathrm{TeSe}_{2}$, a recently approved new mineral species (Rídkošil et al. 2001).

In Table 4, we compare the X-ray powder pattern originally observed for the type material (Johan et al. 1987) with that calculated using the structural parameters obtained in this study. Calculated and observed data match closely.

\section{ACKNOWLEDGEMENTS}

The paper greatly benefitted from the reviews made by Nigel Cook and Chris Stanley. Authors are also grateful to Robert F. Martin for his suggestions on improving the manuscript. The authors thank Filippo Olmi (CNR - Istituto di Geoscienze e Georisorse, sezione di Firenze) for his help during the electron-microprobe analyses. Financial support was provided by the University of Florence (60\% grant) and by M.I.U.R., cofinanziamento 2003, project "Crystal Chemistry of Metalliferous Minerals" awarded to Curzio Cipriani.

\section{REFERENCES}

BAYLISS, P. (1991): Crystal chemistry and crystallography of some minerals in the tetradymite group. Am. Mineral. 76, 257-265.

BINDI, L. \& CIPRIANI, C. (2003a): Plumbian baksanite from the Tyrnyauz W-Mo deposit, Baksan River valley, northern Caucasus, Russian Federation. Can. Mineral. 41, 14751480.

\& (2003b): Crystal structure refinement of winstanleyite, $\mathrm{TiTe}_{3} \mathrm{O}_{8}$, from the Grand Central mine, Tombstone, Arizona. Can. Mineral. 41, 1469-1473.

$\&$ (2004a): Museumite, $\mathrm{Pb}_{5} \mathrm{AuSbTe}_{2} \mathrm{~S}_{12}$, a new mineral from the gold-telluride deposit of Sacarîmb, Metaliferi Mountains, western Romania. Eur. J. Mineral. 16 (in press).

$\&$ (2004b): Ordered distribution of Au and $\mathrm{Ag}$ in the crystal structure of muthmannite, $\mathrm{AuAgTe}_{2}$, a rare telluride from Sacarîmb, western Romania. Am. Mineral. 89 (in press).

Braith, H., Gröbner, J., Langer, G. \& Seitz, M. (2001): Abenteuerliche Mineraliensuche im wilden Norden Mexikos, Moctezumas geheime Schätze: Bambolla, Bambollita und San Miguel. Lapis 1, 11-40.

CipRIANI, C. \& Bindi, L. (2004): Le collezioni del Museo di Mineralogia di Firenze: i tellururi. Museologia Scientifica 19 (2), 283-296.
Clarke, R.M. (1997): Saddlebackite, $\mathrm{Pb}_{2} \mathrm{Bi}_{2} \mathrm{Te}_{2} \mathrm{~S}_{3}$, a new mineral species from the Boddington gold deposit, Western Australia. Aust. J. Mineral. 3, 119-124.

Downs, R.T., BARTELMehs, K.L., GibBs, G.V. \& BoIsEn, M.B., JR. (1993): Interactive software for calculating and displaying X-ray or neutron powder diffractometer patterns of crystalline materials. Am. Mineral. 78, 1104-1107.

Dumas, J.F., Brun, G., Liautard, B., Tedenac, J.C. \& MAURIN, M. (1987): New contribution in the study of the $\mathrm{Bi}_{2} \mathrm{Te}_{3}-\mathrm{Bi}_{2} \mathrm{Se}_{3}$ system. Thermochim. Acta 122, 135-141.

Effenberger, H. \& Pertlik, F. (1987): Hydrothermal und Kristallstruktur von stöchiometrischem Tellurantimon, $\mathrm{Sb}_{2} \mathrm{Te}_{3}$, und Tellurobismutit, $\mathrm{Bi}_{2} \mathrm{Te}_{3}$. Mitt. Österreich. Mineral. Ges. 132, 157-161.

HARKER, D. (1934): The crystal structure of the mineral tetradymite, $\mathrm{Bi}_{2} \mathrm{Te}_{2}$ S. Z. Kristallogr. 89, 175-181.

Ibers, J.A. \& HAMILTon, W.C., eds. (1974): International Tables for X-ray Crystallography, vol. IV. Kynoch Press, Dordrecht, The Netherlands.

Johan, Z., Picot, P. \& RuhLMAnN, F. (1987): The ore mineralogy of the Otish Mountains uranium deposit, Quebec: skippenite, $\mathrm{Bi}_{2} \mathrm{Se}_{2} \mathrm{Te}$, and watkinsonite, $\mathrm{Cu}_{2} \mathrm{PbBi}_{4}(\mathrm{Se}, \mathrm{S})_{8}$, two new mineral species. Can. Mineral. 25, 625-638.

Kato, A. (1970): Kawazulite, $\mathrm{Bi}_{2} \mathrm{Te}_{2} \mathrm{~S}$. In Introduction to Japanese Minerals. Geol. Surv. Japan, Tokyo, Japan.

Kisters, A.F.M., Meyer, F.M., Znamensky, S.E., Seravkin, I.B., ERTL, R.G.W. \& KosArev, A.M. (2000): Structural controls of lode-gold mineralization by mafic dykes in latePaleozoic granitoids of the Kochkar district, southern Urals, Russia. Mineral. Deposita 35, 157-168.

Kovalenker, V.A., NeKrasov, I.Y., Sandomirskaya, S.M., Nekrasova, A.N., Malov, V.S., Danchenko, V.Y. \& DMITRIYEVA, M.T. (1989): Sulfide-selenide-telluride mineralization of epithermal occurrences in the KurileKamchatka volcanic belt. Mineral. Zh. 11(6), 3-18 (in Russ.).

NAKAJIMA, S. (1963): The crystal structure of $\mathrm{Bi}_{2} \mathrm{Te}_{3-x} \mathrm{Se}_{x} . J$. Phys. Chem. Sol. 24, 479-485.

North, A.C.T., Phillips, D.C. \& Mathews, F.S. (1968): A semi-empirical method of absorption correction. Acta Crystallogr. A24, 351-359.

PAuling, L. (1975): The formula, structure, and chemical bonding of tetradymite, $\mathrm{Bi}_{14} \mathrm{Te}_{13} \mathrm{~S}_{8}$, and the phase $\mathrm{Bi}_{14} \mathrm{Te}_{15} \mathrm{~S}_{6}$. Am. Mineral. 60, 994-997.

Ř́ínoŠIL, T., Skála, R., Johan, Z. \& ŠReIN, V. (2001): Telluronevskite, $\mathrm{Bi}_{3} \mathrm{TeSe}_{2}$, a new mineral. Eur. J. Mineral. 13, 177-185.

SHELDRICK, G.M. (1997): SHELXL-97: A Program for Crystal Structure Refinement. University of Göttingen, Göttingen, Germany. 
Shimizu, M., Kato, A. \& Matsubara, S. (1988): Hemusite and paraguanajuatite from the Kawazu mine, Shizuoka Prefecture, Japan. Mineral. J. 14(3), 92-100.

Sokolov, O.B., Skipidarov, S.Y., Duvankov, N.I. \& Shabunina, G.G. (2004): Chemical reactions on the $\mathrm{Bi}_{2} \mathrm{Te}_{3}-\mathrm{Bi}_{2} \mathrm{Se}_{3}$ section in the process of crystal growth. $J$. Crystal Growth 262, 442-448.

SPIRIDONOV, E.M. (1995): Mineralogy of the metamorphosed plutonogenic gold-quartz Kochkar deposit, South Urals 1. Gold telluride ores. Zap. Vses. Mineral. Obshchest. 124(?), 24-39 (in Russ.).

STRunZ, H. (1963): Homöotypie $\mathrm{Bi}_{2} \mathrm{Se}_{2}-\mathrm{Bi}_{2} \mathrm{Se}_{3}-\mathrm{Bi}_{3} \mathrm{Se}_{4}-\mathrm{Bi}_{4} \mathrm{Se}_{5}$ usw. (Platynit, Ikunolit, Laitakarit). Neues Jahrb. Mineral., Monatsh., 154-157.
\& NicKel, E.H. (2001): Strunz Mineralogical Tables. Chemical-Structural Mineral Classification System ( $9^{\text {th }}$ ed.). Schweizerbart, Stuttgart, Germany.

Thompson, R.M. (1949): The telluride minerals and their occurrence in Canada. Am. Mineral. 34, 342-382.

Thorpe, R.I. \& HARRIS, D.C. (1973): Mattagamite and tellurantimony, two new telluride minerals from Mattagami Lake mine, Matagami area, Quebec. Can. Mineral. 12, 55 60 .

Received December 21, 2003, revised manuscript accepted April 3, 2004. 